\title{
Terristory: Land and Language in the Indigenous Short Story - Oral and Written
}

\section{Warren Cariou}

\section{(2) OpenEdition}

1 Journals

Electronic version

URL: https://journals.openedition.org/ces/2356

DOI: $10.4000 /$ ces. 2356

ISSN: 2534-6695

Publisher

SEPC (Société d'études des pays du Commonwealth)

\section{Electronic reference}

Warren Cariou, "Terristory: Land and Language in the Indigenous Short Story - Oral and Written", Commonwealth Essays and Studies [Online], 42.2 | 2020, Online since 30 September 2020, connection on 17 January 2022. URL: http://journals.openedition.org/ces/2356 ; DOI: https://doi.org/10.4000/ces. 2356

This text was automatically generated on 17 January 2022.

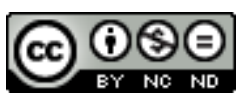

Commonwealth Essays and Studies is licensed under a Licence Creative Commons Attribution - Pas d'Utilisation Commerciale - Pas de Modification 4.0 International. 


\title{
Terristory: Land and Language in the Indigenous Short Story - Oral and Written
}

\author{
Warren Cariou
}

In what ways are stories related to the land?

This question is implicit in much Indigenous literature and storytelling, as well as in a significant amount of the critical literature that examines Indigenous verbal expression. From Richard and Nora Marks Dauenauer's work on Tlingit narratives to Chris Teuton's collaborations with the Cherokee "Turtle Island Liars' Club" to J. Edward Chamberlin's If This Is Your Land, Where Are Your Stories? (2004), discussions of Indigenous oral stories are often particularly concerned with the relationships between the land and the stories. Indigenous literature and, increasingly, Indigenous film, visual art and digital culture are also deeply concerned with enacting and representing Indigenous relationships to the land, whether that land is represented as territory, the environment, Mother Earth, or through particular Indigenous practices of being on the land, such as hunting, harvesting, dancing and practicing ceremony. Margery Fee's Literary Land Claims (2015) examines important examples of this work in a compelling way, positioning story at the nexus of the tensions among colonization, Indigenous resistance and Indigenous sovereignty.

The ubiquity of references to the land in Indigenous expression can make it difficult to talk about what might be understood as the broad picture of land and story in Indigenous literatures and oral cultures. For myself, I have come to this basic question - how are stories related to land? - after spending time contemplating the idea that Indigenous stories can originate from the land, a process described eloquently in Jeannette Armstrong's "Land Speaking" essay (1997), and in Rocky Cree Elder William Dumas's recent observation to me that "the land tells us the stories." These thinkers' understandings of story reverse the trajectory of signification that has been normalized in the western critical tradition since Plato and Aristotle: instead of humans telling stories to mimetically represent the land, it is the land itself that communicates to 
humans through the stories. In my recent work examining the active role of medicine plants in storytelling, I have thought at greater length about the ways in which land relates to story, and this has led me to wonder whether the distinction between story and land is itself part of the colonial process of commodification and separation that has disrupted so much of Indigenous culture and philosophy. ${ }^{1}$ What would the implications be, if we were to consider land and stories as aspects of the same thing or not thing, but action, relation, energy, location? How might we centre this relationship between land and story in our analysis of Indigenous expression (rather than centering one or the other, story or land)? This might be difficult when considering some narratives and environments, but for others I think it could provide us with a useful way of conceptualizing the relationality of Indigenous expression and land-based identity. If we think of land and stories as two aspects of the same phenomenon, this has implications for our understanding of Indigenous sovereignty, agency and ethics. It also helps us to see the vitality and persistence of stories in a different way. Rather than imagining oral stories as evanescent, incorporeal and constantly threatened with disappearance, perhaps this way of thinking would help us to foreground the substantiality of stories, their matter and their resilience. If stories live in the land and are not separate from it, then it is easier to see how they are as real and persistent as anything in the material world.

4 I propose the term terristory as a way of conceptualizing this unity of land and narrative. ${ }^{2}$ In my usage, terristory can be understood as the ground of culture; the living, nurturing, relational medium in which Indigenous communities flourish, and also the entity or being(s) from whom Indigenous people learn their responsibilities. Terristory is a relation, or rather a plural and ongoing set of relations. It is the mode through which Indigenous people are attached to community and to the earth. Even for Indigenous people who have been separated physically from their homelands (through colonial intervention or otherwise), terristory can provide a ground of belonging, in a way that is far more than metaphorical. And while my initial conception of terristory arises from my work on oral stories, I believe that the phenomenon can also be found in all the genres of literature, as well as in film and new media.

5 One group of narratives that exemplify terristory are the ones that refer to specific locations on the land that have been in some way shaped or marked by the events in the story. For example, Omushkego Cree Elder Louis Bird told me several years ago about an unusual lake in Omushkego territory that has cloudy, milky water. This lake, he said, was the site of a violent conflict many generations ago, when a group of Omushkego were killed by their enemies and their bodies were thrown into the water. The story of that violence has remained marked on the land ever since, and Louis Bird says that his community still avoids camping near the area. Many of Mr. Bird's other traditional Omushkego stories take place on particular locations in their territory, and he often goes to great length to describe these locations where, for example, the trickster kills and cooks some geese, or where the great lynx is sprayed by the giant skunk. A few years ago, I was privileged to spend an hour with Mr. Bird scrolling over a Google Maps projection of Omushkego territory, during which he pointed out with great excitement the place where the trickster Weesackaychak caught his geese during their moulting time, and the place where the midget Chakapesh learned how to catch a beaver with his bare hands. These references to specific places in the stories are not simply local colour or embellishments added by the storyteller. They are often a crucial part of the teachings embedded in the narratives, because these stories are almost 
always about how to survive on the land. They contain vital information about the dangers that exist in particular places, and also where to find certain kinds of food at particular times of year, how to prepare it, and how to respectfully give back to the land for the gifts it provides. Every Indigenous oral tradition has examples of stories like this, because the stories have grown out of a profound and long-term relationship between the land and the people. Geography also serves as a mnemonic device in this kind of terristory. When people are out hunting or harvesting on the land, they see these places and remember the stories, and often re-tell the stories as they are passing by. This practice can be understood as a mode of reading the land, which is made more obvious when pictographs or other forms of rock art are also inscribed on the land itself as reminders of particular narratives, linking story with ground in a profoundly material way. Much of the Indigenous rock art and other land-based art on Turtle Island is best understood not as "visual art" in the Western sense, but rather as stories rendered in land: physical expressions of terristory. For example, Elder William Dumas recently told me a story about a place near his home community where different Indigenous nations used to meet, many generations ago, to trade and make treaty and celebrate their alliances. And in this place they held ceremony and they danced, all through the night and through the next day. They danced for so long, the Elder said, that the dancers' feet made furrows in the ground, circles where the dancers had moved together to the beat of the drum. William said that those circles are still there on the land in that place, and he returns there every so often to remember his ancestors and to think about their miskanowak, their paths in life, the paths that marked a series of wheels on the earth for later generations to interpret and wonder at.

Another community where such story-markings on the land are very important is the Okanagan nation, which is the home of many rock paintings, as highlighted by Jeannette Armstrong in her series of poems "From the Landscape of Grandmother" (1990), which depicts a landscape embedded with grids and other shapes of words in the English language. Another Okanagan artist who references a form of imprinting on the land is Elder and storyteller Harry Robinson, as shown in his oral stories told to anthropologist Wendy Wickwire that were later transcribed and published in three books: Write it on Your Heart (2004), Living by Stories (2005), and Nature Power (2013). In many of his stories, Robinson is very concerned with the meaning and the contestation of territory, and Margery Fee undertakes a persuasive reading of his story "Coyote Visits the King" as an exploration of legal and textual modes of enacting Indigenous land claims. I would like to examine another of Robinson's stories collected in that same volume, Write it on Your Heart. In "Coyote Plays a Dirty Trick," Young Coyote is tricked into going to the moon by his underhanded father, and it is when Young Coyote is making his way back down from the moon in a basket that he returns to his home territory in Lytton, British Columbia. Saying "Now this is my country. / This is my place" $(2004,106)$, Young Coyote steps out of the basket and onto the bedrock. Here, in this act of stepping out onto the ground, the hero character leaves a mark on the land something that also happens in many other traditional Indigenous stories. Robinson says,

He walk on there. ${ }^{3}$

And now today

if anybody know where that is

they could still see the tracks

that was marked on the rock.

A few steps, maybe three or four steps right on the rock. 
And that's Coyote's mark when he come out from the basket, the

Young Coyote. (106)

This incident is a particularly clear example of terristory, in which the story narrates the imprinting of marks onto the land itself, and those marks go on to become the geographic mnemonics that help to keep the story itself in circulation, and that also mark this location as what Young Coyote calls "My country [...]. My place." The people who learn Coyote stories from their Elders are thus taught that it is their place too. The location and the story work together to ground Okanagan identity in a particular location on the land.

7 The story goes on to complicate matters significantly however, because Robinson shifts (as he so often does) from legendary time to recent historical time, and recounts what happens when the Canadian Pacific Railway is being built, and colonial surveyors plan to build the railway right over the footprints of Young Coyote. The Okanagan people go to the surveyors and say "Looks like your surveying, your line is right on our history, / We could show you. / We want you to miss it" $(2004,106)$. They offer to tell the white surveyors part of the story - "just a part of that story, / not all" (106-7) - and surprisingly, the white surveyors take up this invitation, and follow the "Indians" to the place. But now, strangely, the marks have disappeared. The storyteller says,

They know.

They seen 'em.

But when they get there with the white man, they never could see 'em.

They could never see that footmark [...].

Just because the white man was with 'em. (107)

For some reason, these marks on the ground are rendered invisible by the presence of non-Okanagan people, and specifically the presence of white surveyors, who bring with them a particular set of assumptions about reading and reconfiguring the land. Railway construction in hilly and mountainous territory, after all, often involves the blasting away of bedrock that might otherwise have seemed permanent. To me this sudden elusiveness of Young Coyote's footprints says something about the disruptive nature of the colonial mindset, which introduces a separation between the story and the land. The Okanagan people can remember the story, and they know they are in the right place, but the two elements of land and story are no longer unified for them.

Nonetheless, the Okanagan people successfully convince the surveyors that they should move the railway, and they do so by telling part of the Coyote story. So it seems the story still retains a power to protect Okanagan sovereignty over their sacred site, even though Young Coyote's tracks are not locatable when the surveyors are present. However, this is not the end of Robinson's story, and we learn that the coming of the surveyors has had longer-term effects. Even after the railway is re-routed and the white men leave the place, the Okanagan people still have trouble seeing Young Coyote's tracks. For some of them, the tracks are not completely gone, but they are not as visible as they once were. So even though the site of terristory is not physically destroyed, and the Okanagan people can claim a rare victory in defending their land from physical colonial intrusion, something important about that connection of land and story is altered by the one-time presence of the surveyors. Perhaps it is because the surveyors represent such a contrary understanding of the relationship between land and culture. It was when this contrary idea was first introduced that the Okanagan people needed to initiate the practice of what would later become understood as a land claim, where they tell a traditional story to indicate to colonial authorities that they 
have a prior relationship with a particular place. For the Okanagan people, there is no need for their stories to make a claim to the land when their connection to the land is not contested by an outside agent - when terristory exists in its full strength and unity. The need for a land claim comes at the moment when terristory has been disrupted, and the land claim can be understood as an attempt to re-assert the primacy of terristory.

Viewing this situation through a lens of terristory is one way of emphasizing the continuity of the Okanagan people's connection to the land, rather than focusing on disruption. Even though their view of this land-form is not entirely the same after the surveyors have been there, some Okanagan people can still see Young Coyote's tracks even after the white men have brought their world-views to the place. Thus the Okanagan people are maintaining their culture, even through various sources of disruption. In fact, if we go back to the earlier part of the story when Harry Robinson first mentioned the tracks of Young Coyote, he says "And now today / if anybody know where that is / they could still see the tracks" $(2004,106)$. So while he acknowledges the difficulties created by colonial ideology, he is asserting here that the tracks are still visible for those who have the knowledge of the place and the story (and it's interesting that he is speaking to a white woman while he says this, and while he tells her the story that will help to make the Young Coyote's tracks visible). To me, this demonstrates that terristory is a mode of survivance as well as a link to traditional understandings of land and narrative. It is entirely possible to experience terristory within a colonial context, and the persistence of terristory in such conditions is in fact a sign of continued Indigenous presence and vitality. It allows us to see colonialism as temporary rather than as a permanent new reality, while terristory is understood as an ongoing relationship, from the deep past to the foreseen future.

This is why it is very possible to maintain a relationship of terristory within an urban context or some other overtly colonized landscape: because in a sense, terristory is more about the human attitude toward the land and stories than it is about "what has happened to the land," or how it has been reconfigured to suit colonial uses. Attuning our senses to find terristory within our local landscapes is a way of asserting that continuity of connection. For example, throughout her collection Dancing on Our Turtle's Back, Anishinaabeg writer Leanne Simpson recounts activities where Anishinaabeg perform their relationships to the land despite colonial barriers and boundaries. One example of Simpson's focus on revealing terristory within an unlikely-seeming urban context is when she writes about a performance by Anishinaabeg artist Rebecca Belmore in a Price Chopper grocery store parking lot in Peterborough, Ontario. The performance was done on the same day that the Curve Lake First Nation held what Belmore calls "a ceremony across the street to rebury the body of a 2,000-year-old Indigenous man uncovered when the parking lot was created" (rebeccabelmore.com). The performance itself is clearly influenced by that event - the uncovering of an Indigenous ancestor's body when the urban, colonial, capitalist space of the grocery store was created - and in that way it can be seen as an assertion of terristory, a recognition that this land is full of Indigenous lives and stories even when it seems to have been remade into a colonial form. As can be seen in the video documentation of the performance on Belmore's website, the X's and erasures of the performance, as well as the artist's gestures toward the compartmentalization of nourishment within 
capitalism, all resonate with a critique of colonial forms of relationship to the land. In her description of this event, Leanne Simpson focuses on

the transformative nature of the performance in terms of space [...]. I was transported into a world where Nishnaabeg flourished and where justice prevailed,

a world where my voice and my meanings mattered. $(2011,97)$

The space itself is thus being remade in the process of Belmore's performance, which is then incorporated into Simpson's own story. Simpson goes on to say that the performance "has altered the landscape in my memory and in the memory of everyone who witnessed her performance" (98). This alteration is, implicitly, the revealing of the terristory of that place and that performance, as a unified experience, so that the location is no longer understood as a venue of capitalist/colonial forms of nourishment, but rather as a re-connection to the deeper relationship with the place. One can imagine that every time Leanne Simpson passes by the Price Chopper store, she thinks of it as a site of a profound storytelling, a place where a hero of her culture has made important marks on the land itself.

11 Earlier in Dancing on Our Turtle's Back, Simpson re-tells a traditional Anishinabeg story about gaining nourishment from the land, in which Nanabozho finds the gdigaa bzhiwag (bobcats) paralyzed by their helpless addiction to the dripping maple sap, which leads them to abandon all their preparations for the winter and to simply live for the beautiful taste of the sap. This story is all about how to survive - and how not to survive - on the bounty provided by the land, and Nanabozho's main tactic for saving the bobcats from themselves is to water down the tree sap so that it requires a great deal of work for the gdigaa bzhiwag to create maple syrup, and thus in the future they can only consume it in moderation. This story is set in the deep time of legend, but it is also set in Simpson's present time, and in the place - the sugar bush - where she lives. As a story of how to survive on the land, it is already an example of terristory, but she shows it to be a particularly decolonial type of terristory when she reveals in a footnote that this story is one that she learned originally in a book, a collection of Ojibway stories created by a non-Indigenous editor in 1983, The Woodland Indians of the Western Great Lakes.

12 Simpson criticizes these dry, anthropological collections of "Indian legends," but she also informs us that she has been re-telling this story in her own way, and "in the context of my clan affiliation, my contemporary life and my interpretation of Anishinaabeg thought" $(2011,83)$. Over the years of telling this story, to her own children and to others in the community, it has become different: "This re-telling bears little resemblance to the published versions" (83). To me this is a fascinating example of re-oralizing a story that had once been written down, and in the process of doing this, Simpson is implicitly decolonizing this version of it as well, and bringing the story closer to the relation of terristory, by telling it in connection to her own relationship with the sugar bush in her home territory. This re-telling is a way of reclaiming and recontextualizing the story, making it live again, and connecting it to her own specific experiences on particular land.

13 Similarly, Duncan Mercredi's performance poem "the city is red" reverberates with his vibrant sense of Winnipeg as an Indigenous space, as still very much "the land" even though it is urban. Mercredi has spoken of the streets of Winnipeg as his trapline, and his practice of walking the city, searching for voices and stories and reaffirming his own personal relationship to the land, is clearly connected to traditional hunting and harvesting activities. Even though many of the narratives Mercredi references in the 
poem are legacies of colonial violence and displacement and racism, he still enacts a deep love and respect for both the land and the stories it holds. The pain is part of this relationship, part of the truth he has uncovered in his decades of traveling his urban trapline. Mercredi shows here that terristory is in some ways a state of mind, or an attitude toward land and story: a belief in their deep connectedness. The maintenance of that belief is in a powerful way an assertion of Indigenous connection to the place. He writes:

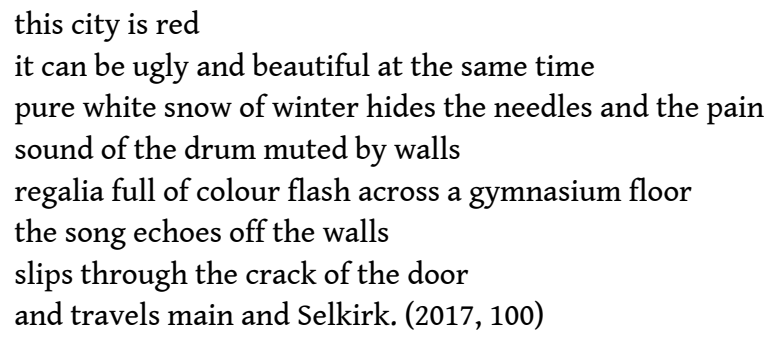

Like other examples of terristory, this poem enacts a long-term connection to the land that presents colonialism as a temporary incursion into a continuous relationship between Indigenous people and the land. While the city is a place of racial intolerance and Indigenous suffering much of the time in the present, and while the land is the repository of Indigenous blood and bones that are the result of colonial violence, at the end of the poem Mercredi addresses settlers, and gestures toward a future in which their hold upon the land will end:

this city is red

a blood red history you have chosen to ignore

and when you become dust

$i$ will dance on your ashes

and when the seed of a new flower blossoms

where your ashes have settled

becoming one with the soil

i will dance again (103)

This foreseen fertility of the soil in a future decolonized land is an echo of the decolonizing performativity of the ghost dance, as Sakej Henderson imagines in his article "Postcolonial Ghost Dancing" (2000). Mercredi's insistent repetition of the present tense statement "this city is red" indicates that the dance also continues in the present, knitting together land and story for Indigenous people who see the city as a space of ongoing relationship between our stories and our land.

If we think of land and story as being intimately entwined in the practice of terristory, then this might help to provide a better explanation of why it is so hurtful to Indigenous communities when stories are appropriated or misused. The land of Turtle Island, we know, has been stolen from Indigenous people through various means, most of which have involved duplicitous uses of language. When Europeans arrived seeking to claim these territories for themselves, they relied on their own legal formulations such as the Doctrine of Discovery and the principle of terra nullius, the supposition that the land was empty or unoccupied, despite the fact that millions of people lived on Turtle Island. But it is clear that what has been stolen is not only the land, but also in many cases the stories that have been connected to that land. With the loss of access to traditional places of gathering, through the imposition of private property, the idea of "Crown land," and the massive land-grabs of extractive industry and infrastructure including roads, train tracks and pipelines, both territory and stories have been taken away from Indigenous people. The appropriation of Indigenous stories for other uses 
needs to be understood in the same context as this, as an extension of the doctrine of terra nullius, the idea that land was just there for the taking because it was not being "used" in a proper colonial way. When we consider land and stories to be aspects of the same energy, then the appropriation of stories is essentially indistinguishable from the theft of land.

I am reminded of Greg Younging's diagnosis of a counterpart to the doctrine of terra nullius, which he calls "gnaritas nullius" or "nobody's knowledge" $(2018,109)$. Younging argues that the colonial notion of gnaritas nullius is based on the idea that Indigenous knowledge should be freely available to all, because it exists in oral forms and because it is often very old. He shows that gnaritas nullius is the basis of how Western copyright deals with traditional Indigenous stories, and he demonstrates how this legal framework is being used even today to support the idea that Indigenous knowledge should be regarded as being in the public domain, and thus not in control of Indigenous people. I believe this phenomenon is also visible in the broader realm of literature that represents Indigenous stories without Indigenous consent. While it is no longer socially acceptable for settlers to invoke the doctrine of terra nullius as a justification for the colonization of Turtle Island, the ideology of gnaritas nullius is still very much alive and well today, with artists continuing to take Indigenous stories without proper permissions, ceremonies, or protocols, simply because these stories seemed to be "there for the taking." Understanding these acts of appropriation from the perspective of terristory provides a stark view of what is really at stake when Indigenous people's connection to their traditional stories is undermined in this way. The stories, like the land, are the source of cultural and physical sustenance. In this context it is possible to see how the appropriation of stories is very similar to the theft of land - and no less devastating to Indigenous peoples.

\section{BIBLIOGRAPHY}

ARMSTRONG, Jeannette. 1990. "From the Landscape of Grandmother." In Breath Tracks, 2-18.

Penticton, BC: Theytus Books.

ARMSTRONG, Jeannette. 1997. “Land Speaking." Speaking for the Generations. Ed. Simon Ortiz, 172-91. Tucson, AZ: University of Arizona Press.

BELMORE, Rebecca. 2010. “X.” Performance in Price Chopper Grocery Store Parking Lot Peterborough Ontario. Video recording at rebeccabelmore.com.

CARIOU, Warren. 2018. “Sweetgrass Stories: Listening for Animate Land.” Cambridge Journal of Postcolonial Literary Inquiry 5, no. 3: 338-52.

CHAMBERLIN, J. Edward. 2004. If This Is Your Land, Where Are Your Stories? Finding Common Ground. Toronto: Vintage Canada.

FEE, Margery. 2015. Literary Land Claims: The "Indian Land Question" from Pontiac's War to Attawapiskat. Waterloo: Wilfrid Laurier University Press. 
HENDERSON, James Sakej. 2000. "Post Colonial Ghost Dancing: Diagnosing European Colonialism." In Reclaiming Indigenous Voice and Vision, edited by Marie Battiste, 57-76. Vancouver: University of British Columbia Press.

HENZI, Sarah. "Beyond Terri(s)tories." Conference presentation. Indigenous Literary Studies Association. Sto:lo First Nation. June 19, 2017

MERCREDI, Duncan. 2017. “this city is red.” Prairie Fire 38, no. 1: 100-103.

ROBINSON, Harry, and Wendy WICKWIRE. 2004. Write It on Your Heart: The Epic World of an Okanagan Storyteller. Vancouver: Talonbooks.

ROBINSON, Harry, and Wendy WICKWIRE. 2005. Living by Stories: A Journey of Landscape and Memory. Vancouver: Talonbooks.

ROBINSON, Harry, and Wendy WICKWIRE. 2013. Nature Power: In the Spirit of an Okanagan Storyteller. Vancouver: Talonbooks.

SIMPSON, Leanne. 2011. Dancing on Our Turtle's Back: Stories of Nishnaabeg Re-Creation, Resurgence, and a New Emergence. Winnipeg: ARP Books.

YOUNGING, Greg. 2018. Elements of Indigenous Style: A Guide for Writing by and about Indigenous Peoples. Edmonton: Brush Education.

\section{NOTES}

1. See my article "Sweetgrass Stories: Listening for Animate Land" (2018).

2. This coinage has been used in several other contexts before, and I especially want to acknowledge Sarah Henzi's use of the word in her paper title "Beyond Terri(s)tories" at the 2017 Indigenous Literary Studies conference in Sto:lo territory.

3. Wickwire has rendered Robinson's English as he spoke it, rather than choosing to "correct" the grammar of sentences such as this one. I believe that this is not only the ethically appropriate way to reproduce the story in print, but it also more effectively imparts the flavour of his storytelling.

\section{ABSTRACTS}

This paper examines the relationship between land and narrative in oral and written short stories by Indigenous artists of Turtle Island. It argues that certain Indigenous stories should be understood as inseparable from particular locations in the writer's or teller's traditional territory. The unity of story and place in these works is a powerful source of Indigenous sovereignty and an inspiration for contemporary Indigenous resurgence.

\section{INDEX}

Keywords: Indigenous, storytelling, orality, territory, relationality 


\section{AUTHOR}

\section{WARREN CARIOU}

University of Manitoba

Warren Cariou is a Professor in the Department of English, Theatre, Film \& Media at the University of Manitoba, where he also directs the Centre for Creative Writing and Oral Culture. He has published works of fiction and memoir as well as scholarly writing about the storytelling traditions, literature and environmental philosophies of Canadian Indigenous communities. 